\title{
Satyendra Nath Bose His Life and Times
}

Selected Works (With Commentary) 
This page intentionally left blank 


\section{Satyendra Nath Bose His Life and Times}

Selected Works (With Commentary)

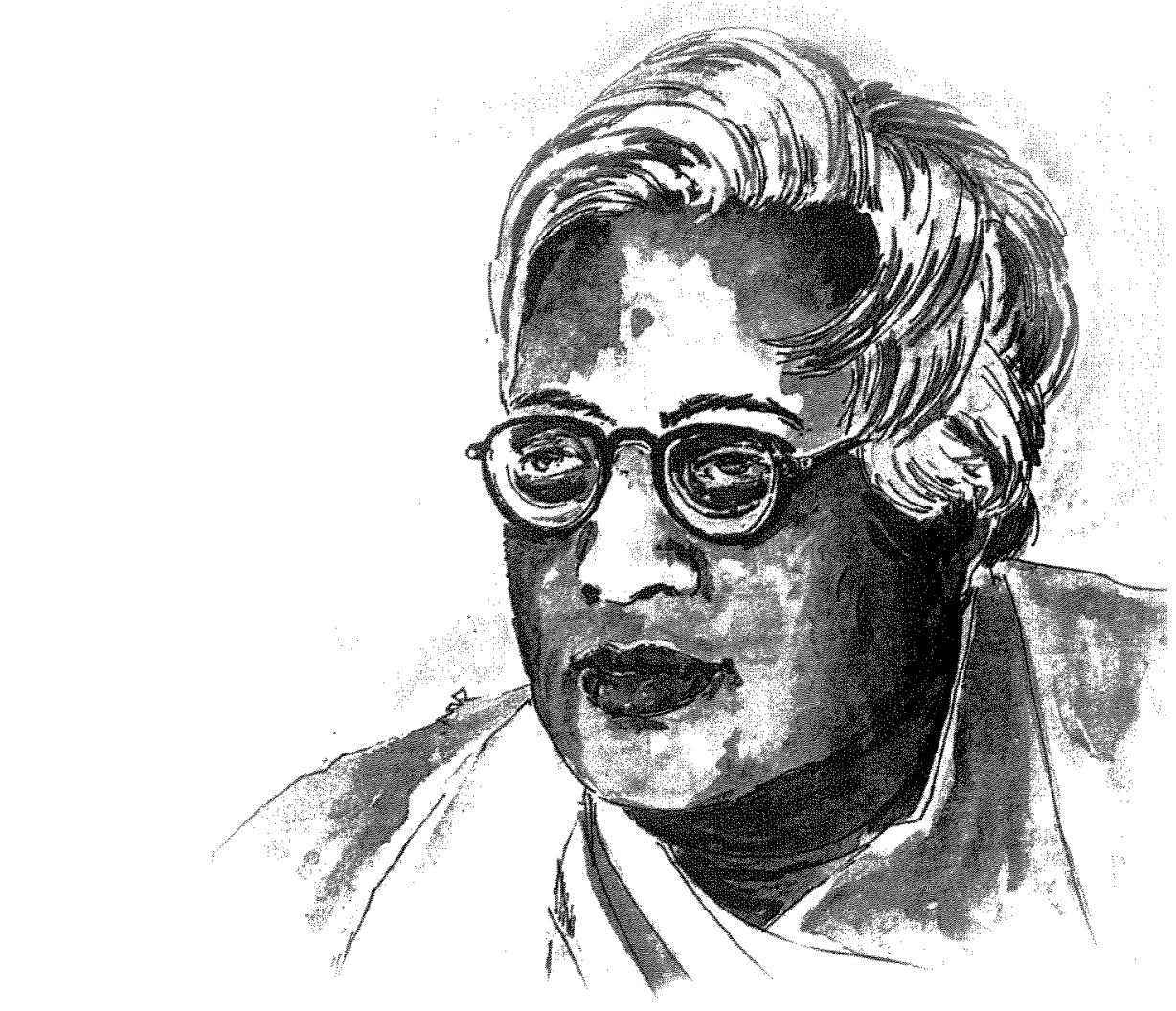

Edited by

\section{Kameshwar C. Wali}

Syracuse University, USA 


\section{Published by}

World Scientific Publishing Co. Pte. Ltd.

5 Toh Tuck Link, Singapore 596224

USA office: 27 Warren Street, Suite 401-402, Hackensack, NJ 07601

UK office: 57 Shelton Street, Covent Garden, London WC2H 9HE

\section{British Library Cataloguing-in-Publication Data}

A catalogue record for this book is available from the British Library.

\section{SATYENDRA NATH BOSE - HIS LIFE AND TIMES Selected Works (With Commentary)}

Copyright (C) 2009 by World Scientific Publishing Co. Pte. Ltd.

All rights reserved. This book, or parts thereof, may not be reproduced in any form or by any means, electronic or mechanical, including photocopying, recording or any information storage and retrieval system now known or to be invented, without written permission from the Publisher.

For photocopying of material in this volume, please pay a copying fee through the Copyright Clearance Center, Inc., 222 Rosewood Drive, Danvers, MA 01923, USA. In this case permission to photocopy is not required from the publisher.

ISBN-13 978-981-279-070-5

ISBN-10 981-279-070-5

ISBN-13 978-981-279-071-2 (pbk)

ISBN-10 981-279-071-3 (pbk) 


\section{Foreword}

The year 2005 was celebrated worldwide as the centenary of Einstein's miraculous year, 1905, as well as for his life and work. During a period of twelve months (1905), he published five papers that changed the face of physics - two of which laid the foundations of the Special Theory of Relativity; a paper on the quantum nature of radiation in explaining the PhotoElectric effect; papers on the theory of Brownian motion, and on molecular dimensions and the calculation of Avogadro's number. In 1924, almost two decades after the miraculous 1905, and almost a decade after his famous theory of gravitation in 1915, Einstein was involved in another important discovery of $20^{\text {th }}$ century physics - the birth of the new quantum statistics to become known as the Bose-Einstein statistics. It all began with a letter and a short article. A relatively unknown young man, Satyendra Nath Bose, from Dacca University in East Bengal (now Bangladesh) wrote to Einstein, claiming he had derived Planck's law for black body radiation without recourse to classical electrodynamics. Bose further wrote that if Einstein thought it was important, he would be grateful if he (Einstein) could arrange its publication in Zeitscrift fur Physik, as he, Bose, did not know German well enough.

Einstein translated the paper himself and got it published with a note added saying, "Bose's derivation of Planck's law appears to me an important step forward. The method used here also yields the quantum theory of ideal gas, as I shall show elsewhere." Indeed in a matter of weeks, Einstein published his paper extending Bose's work to monoatomic gas and followed it up with another paper within months, predicting according to the new theory the possibility of a new state of matter, the Bose-Einstein condensate. Highlighting the importance of this development, Abraham Pais in his celebrated book, "Subtle is the Lord," on Einstein says, "For Einstein this period was only an interlude. He was already engrossed in his search for a unified theory. Such is the scope of his oeuvre that his discoveries in those six months do not even rank among his five main contributions, yet they alone would have sufficed for Einstein to be remembered forever."

Einstein's recognition of Bose's work had an immediate impact on Bose's life and career. He was granted study leave from his university for two years "with a stipend, a separation allowance for the family, with sumptuous travel allowance with round trip fare." Although Bose was primarily a theoretical physicist at the time, he spent his first year abroad gaining first-hand experience working in the crystallographic laboratories of Maurice de Broglie and the radioactivity research laboratories of Madam Curie before going to Berlin to meet Einstein in October of 1925. Berlin was humming with the excitement of the dawn of the new quantum mechanics with the visits and seminars of Heisenberg and Schrodinger. Einstein introduced Bose to several prominent physicists including Otto Hahn, Lise Meitner, Fritz Haber and Walter Gordon. He came to know Hermann Mark and worked closely in his laboratories of $\mathrm{X}$-ray crystallography.

Bose's two-year stay in Europe marked, in many ways, a turning point in his career as a teacher and researcher. He realized the importance of experimental research in the advancement of science. On his return, he occupied himself mostly with setting up an X-ray crystallography laboratory at Dacca University. He designed and built his own equipment, requiring that his 
students do the same. On other fronts he devoted himself almost exclusively to teaching and guiding research. He also held various administrative positions as Department Head, Dean of the Faculty of Science and Provost. In 1945, he left Dacca to return to his alma mater, the University of Calcutta as the Khaira Professor of Physics. He retired from the University of Calcutta in 1956, spent a year as the Vice Chancellor at the Viswa-Bharati University and finally lived the remainder of his years in Calcutta until his death in 1974.

Bose, a brilliant and inquisitive scholar throughout his career, lived during a period of great change in India. He witnessed the partition of Bengal, his home in 1905. Instigated by Lord Curzon, one of the most imperialist viceroys of India, this action resulted in the rise of a strong nationalist movement against the British. Bose was one of a group of accomplished intellectuals motivated by national fervor to excel academically and creatively to prove their competitiveness with their counterparts in the western world. He was active politically throughout his life, serving on many committees to further scientific and industrial development in India after independence.

Bose was an inspiring figure to many outside of the physics community. His love for stimulating conversations, wide ranging interests in all human endeavors, his intellectual fervor, his scientific accomplishments beyond physics and not least, his association with Einstein established his legendary reputation in India.

I had the occasion to see S.N. Bose briefly in 1952 as a post-graduate student at the Banaras Hindu University working in the spectroscopy laboratory of R.K. Asundi. Bose's unannounced visit made us students gather quickly around the tea table. My only recollection is that we students sat quietly while two stalwarts (Asundi and Bose) conversed. I remember vividly a handsome, dark skinned Bengali with a head full of gray hair and dark penetrating eyes. We students were also invited on a traditional evening boat trip on the Ganges, yet we remained at a distance with no personal encounter.

Years later, in the 1970 's, an anecdotal story came to me whilst writing CHANDRA, the biography of S. Chandrasekhar. Chandra recounted a story told by Sir C.V. Raman, his famous uncle during a boat trip on the Hugli River in Calcutta in 1928. Raman told Chandra how S.N. Bose, after attending Raman's lecture, was the first to recognize the importance of his discovery.

Bose presciently remarked to Raman, "You have made an important discovery. It will be known as Raman Effect and you will get a Nobel Prize."

As part of the Einstein centenary celebrations in 2005, I was privileged to present talks about the discovery of Bose-Einstein statistics at the American Physical Society meetings in Tampa, Florida and Lincoln, Nebraska, and at the invitation of the editors of Physics Today, I wrote a brief article, "The Man behind Bose Statistics," published in the October 2006 issue. That led to this assignment from Dr. K.K. Phua, of World Scientific Publishing Co., to edit a book on Bose, his life and his works. I have collected together all his physics and mathematical physics papers along with selected articles based on his lectures and addresses. Also included are some miscellaneous pieces translated from his Bengali writings. Some published articles by others provide a historical perspective on the discovery of Bose-Einstein statistics. The remaining articles reflect upon and shed light on Bose as a teacher, an intellectual and a national figure. 


\section{Acknowledgments}

I am grateful to Sushanta Dattagupta and Arup Kumar Raychaudhuri, former and current Directors of the S.N. Bose National Center for Basic Sciences, Calcutta, India for granting permission to reproduce articles and pictures from The Man and His Works Part I: Collected Scientific Papers and Part II: Life, Lectures and Addresses, Miscellaneous Pieces*, S.N. Bose, National Center for Basic Sciences, Calcutta (1994), to John Stachel and Supurna Sinha for many helpful discussions and providing me documents and pictures, and Falguni Sarkar for permission to use pictures and material from his article "Ode to grandpa: Tribute to S.N. Bose." My special thanks to Etienne Eisenmann for information concerning Jacqueline Eisenmann with pictures and letters, Sauer Tilman for the files from the Einstein Archives of the Hebrew University, Jerusalem and all the contributors. Many thanks also to Achala Wali for editing parts of this book and Heather Kirkpatrick for assembling the articles, pictures and preparing the manuscript. Finally, I like to thank the Senior Editor, Lakshmi Narayanan and her colleagues at World Scientific for the excellent job they have done in producing this volume.

*The numbers at the bottom left-hand corner of the pages of articles reproduced in this volume refer to the actual page numbers of articles in these two volumes. 
This page intentionally left blank 


\section{Contents}

Foreword

Satyendra Nath Bose - His Life and Times

K. C. Wali

$\mathrm{XV}$

\section{Selected Scientific Papers}

\section{A. Early Papers - Classical Physics}

On the Influence of the Finite Volume of Molecules on the Equation of State [Phil. Mag.

Ser. 6, 36, pp. 199-203 (1918)]

M. N. Saha and S. N. Basu

On the Herpolhode [Bull. Cal. Math. Soc. 11, pp. 21-22 (1919)]

S. Basu

On The Equation of State [Phil. Mag. Ser. 6, 39, p. 456 (1920)] M. N. Saha and S. N. Basu

\section{B. Quantum Mechanics and Quantum Statistics}

On the Deduction of Rydberg's Law from the Quantum Theory of Spectral Emission [Phil. Mag. 40, pp. 619-627 (1920)]

S. N. Basu

Plancks Gesetz und Lichtquantenhypothese [Z. Physik 26, pp. 168-171 (1924)] Bose

Planck's Law and the Light-Quantum Hypothesis [English translation of $Z$. Physik 26, pp. $168-171(1924)]$

Bose

Wärmegleichgewicht im Strahlungsfeld bei Anwesenheit von Materie [Z. Physik 27, pp. 384-393 (1924)]

S. N. Bose

Thermal Equilibrium in the Radiation Field in the Presence of Matter [English translation of Z. Physik 27, pp. 384-393 (1924)]

S. N. Bose 
A Note on Dirac Equation and the Zeeman Effect [Ind. J. Phys. 17, pp. 301-308 (1943)] S. N. Bose and K. Basu

\section{The Ionosphere - Mathematical Physics}

Anomalous Dielectric Constant of Artificial Ionosphere [Sci. \& Cult. 3, pp. 335-337 (1937)]

S. N. Bose and S. R. Khastgir

On the Total Reflection of Electromagnetic Waves in the Ionosphere [Ind. J. Phys. 12, pp. 121-144 (1938)]

S. N. Bose

On the Complete Moment-Coefficients of the $\mathrm{D}^{2}$-Statistic [Sankhya - Ind. J. Stat. 2, pp. 385-396 (1936)]

S. N. Bose

On the Moment-Coefficients of the $\mathrm{D}^{2}$-Statistic and Certain Integral and Differential Equations Connected with the Multivariate Normal Population [Sankhya - Ind. J. Stat. 3, pp. 105-124 (1937)]

S. N. Bose

Studies in Lorentz Group [Bull. Cal. Math. Soc. 31, pp. 137-147 (1939)] S. N. Bose

The Complete Solution of the Equation: $\nabla^{2} \phi-\frac{\partial^{2} \phi}{c^{2} \partial t^{2}}-k^{2} \phi=-4 \pi p(x y z t)$ [Proc. Nat. Inst. Sc. India 7, pp. 93-102 (1941)]

S. N. Bose and S. C. Kar

On an Integral Equation Associated with the Equation for Hydrogen Atom [Bull. Cal. Math. Soc. 37, pp. 51-61 (1945)]

S. N. Bose

\section{Unified Field Theory}

The Identities of Divergence in the New Unitary Theory [English translation of Comptes rendus de L'Academie des Sciences 236, pp. 1333-1335 (1953)]

Note of S. N. Bose, presented by L. de Broglie

A Unitary Field Theory with $\Gamma_{\mu} \neq 0$ [English translation of Le Jour de Phys et le Radium (Paris), 14, pp. 641-644 (1953)]

S. N. Bose

Certain Consequences of the Existence of the Tensor $g$ in the Affine Relativistic Field [English translation of Le Jour de Phys et le Radium (Paris), 14, pp. 645-647 (1953)] 
The Affine Connection in Einstein's New Unitary Field Theory [Ann. Math. USA 59, pp. 171-176 (1954) (Princeton University, NJ)]

S. N. Bose

Solution of a Tensor Equation Occurring in the Unitary Field Theory [English translation of Bull. Soc. Math. 83, pp. 81-88 (1955)]

S. N. Bose

182

\section{Satyendra Nath Bose}

\section{A. Lectures and Addresses}

Science in Education [Man and His Work, Part II, pp. 127-133]

Proc. The Bengal Education Week, I, pp. 56-64 (1936)

Visva-Bharati [Man and His Work, Part II, pp. 141-144]

Convocation address delivered at Visva-Bharati on 15 January 1957

Higher Education and Us [Man and His Work, Part II, pp. 145-150]

Convocation address delivered at Calcutta University in 1962

Man in the Scientific Age [Man and His Work, Part II, pp. 157-161]

Address at a Symposium in Tokyo, Japan 1962

The Mother Tongue [Man and His Work, Part II, pp. 162-167]

Address delivered in Bengali at the "Angrezi Hatao Conference" [Banish English

Conference] at Hyderabad in October 1962

Education and Science [Man and His Work, Part II, pp. 168-174]

Convocation address delivered at Ranchi University on 11 May 1963

On His Seventieth Birthday [Man and His Work, Part II, pp. 175-180]

Address given in Bengali at the Mahajati Sadan Auditorium, Calcutta on 1 January 1964

The Krishnan Memorial Lecture, 1971 [Man and His Work, Part II, pp. 188-195]

Lecture delivered at the National Physical Laboratory on 12 March 1971

Education and the New Age [Man and His Work, Part II, pp. 196-199]

Address delivered in Bengali at the Rabindra Bharati University on 10 May 1971

At the Calcutta University Convocation 1973 [Man and His Work, Part II, pp. 200-203] Convocation address delivered in Bengali at Calcutta University on 16 June 1973

Address at Seminar on Scientific Contributions of S. N. Bose [Man and His Work, Part II, pp. 204-206] Speech delivered at the Calcutta Mathematical Society on 29 December 1973 


\section{B. Miscellaneous Pieces}

A Scientist's Apologia [Man and His Work, Part II, pp. 219-223]

The Progress of Science in Ancient India [Man and His Work, Part II, pp. 224-229]

The Early Phase of My Explorations in Science [Man and His Work, Part II, pp. 244-249]

Einstein (1935) [Man and His Work, Part II, pp. 279-284]

In the Company of Madame Curie [Man and His Work, Part II, pp. 290-291]

\section{Historical Perspectives; Reflections}

A Loss of Identity: The Birth of Quantum Statistics ['Subtle is the Lord' The Science and Life of Albert Einstein (Clarendon Press, Oxford, 1982)]
A. Pais

Bose Statistics: A Historical Perspective [The Man and His Work, Part I, pp. 35-70]

$$
\text { P. Ghose }
$$

Who Discovered the Bose-Einstein Statistics? [Symmetries in Physics (1600-1690); Proc. 1st Int. Meeting, Saint Feliu de Guixoles, Catalonia, Spain (September 20-26, 1983)

pp. 222-250]

$$
\text { S. Bergia }
$$

Addendum

$$
\text { P. Ghose }
$$

Nobel Lecture: Bose-Einstein Condensation in a Dilute Gas, the First 70 Years and Some Recent Experiments* [Rev. Mod. Phys. 74, 875 (2002)]

E. A. Cornell and C. E. Wieman

Experimental Proof of the Spin of the Photon

C. V. Raman and S. Bhagavantam

Evidence for the Spin of the Photon from Light Scattering

C. V. Raman and S. Bhagavantam

S. N. Bose: The Man [Talk presented at a seminar on Albert Einstein, Dhaka, 30 May, 2005; Proc. Bangladesh Academy of Sciences]

$$
\text { P. Ghose }
$$

Satyendranath Bose: Co-Founder of Quantum Statistics [Am. J. Phys. 40, 1212 (1972)] 
Einstein and Bose [Einstein from ' $B$ ' to ' $Z$ ' (Birkhäuser, 2002), pp. 519-538]

$$
\text { J. Stachel }
$$

A Conversation with Satyendranath Bose about Five Decades Ago - Some Recollections [Current Science 78, pp. 636-638 (2000)]

S. Ramaseshan

Satyen Bose in Berlin [The Physicist, Bulletin of the Bangladesh Physical Society (1995), pp. 17-21]

$$
\text { P. Sinha }
$$

Satyendra Nath Bose: Historical Notes and Reflections

E. C. G. Sudarshan

Satyendra Nath Bose - Some Vignettes of a Many-sided Personality D. N. Bose

Contributors 
This page intentionally left blank 


\title{
Satyendra Nath Bose - \\ His Life and Times \\ (1894-1974)
}

\begin{abstract}
Never accept an idea as long as you are yourself not satisfied with its consistency and the logical structure on which the concepts are based. Study the masters. Those are the people who have made significant contributions to the subject. Lesser authorities cleverly bypass the difficult points.
\end{abstract}

Satyendra Nath Bose

Considering Bose's legendary association with Einstein and a remarkable discovery to his credit, one might expect him to be better known in the international sphere. However, little is known about him outside India. Quite often he is thought to be from Germany, name misspelt without the "umlaut" on "o". Even in India, he is often confused with Jagadish Chandra Bose, who was the first $19^{\text {th }}$ century scientist from the country to have received worldwide recognition for his experiments on wireless transmission as well as his experiments with plants, demonstrating such vital characteristics in them as growth, nervous system and other distinguishing features of animal life.

The first quarter of the $20^{\text {th }}$ century was indeed a golden period in the history of India, and the province of Bengal in particular. Considered more progressive than other provinces, it was the first to accept and adopt British ways of life and literature. Bengal was also the first to rebel against the colonial masters, especially, when in 1905 (coincidentally the Einstein miracle year), Lord Curzon partitioned Bengal into two, West and East Bengal to curb the rising nationalist movement. Bose, a brilliant student throughout his career, joined a group of accomplished intellectuals motivated strongly to excel in arts and sciences and other creative endeavors to demonstrate their national fervor and to prove that they were competitive with their counterparts in the western world.

\section{Beginnings}

Satyendra Nath (Bose) was born on January 1, 1894 in Kolcuta (formerly known as Calcutta, the capital of British India). He was the eldest child and the only son in a family of six daughters of Surendra Nath and Amodini Bose. Bose's family, with two generations of English education, belonged originally to the village Bara Jagulia in the district of Nadia, known for its traditional learning of Sanskrit scriptures and its scholars. According to family records, the family lived in this village for over three centuries. With the advent of British Raj and the emergence of Calcutta, Nadia lost its importance and the family moved to Calcutta. The house 
in which Satyendra Nath was born and grew up is supposed to have been built by his greatgreat-grandfather and rebuilt with extensive modifications by his father.

Satyendra Nath's grandfather, Ambikacharan, was probably the first "English-educated" in the family. He worked as an accountant in the British military commissariat and spent the most part of his life in northwestern parts of India. Surendra Nath, his eldest son, after completing his primary education in the village, studied in Meerut Government School. His education was interrupted due to the sudden death of his father. With the family responsibilities on his shoulders, he took an accountant's examination, qualifying himself as an accountant. He was working as an accounts clerk in the East India Railways when Satyendra was born. Although working in the British civil service, Surendra Nath was a part of the rising Englisheducated middle class that was deeply influenced by the mid-nineteenth century rationalism and individualism of European culture. At the same time, he was also equally becoming a part of the rising nationalism against the British colonization. With a broad range of interests including mathematics, science and philosophy, and inspired by the nationalist ideal that the future of India demanded the development of science and technology, he became the founder of an independent chemical and pharmaceutical company in 1903. Amodini, Satyendranath's mother was the daughter of Motilal Chowdhary, a renowned lawyer and a classmate of Bankimchandra Chatterjee, one of the early and famous novelists of Bengal. With only a nominal education in a primary school, she adapted well in the extended family of the Boses, and was apparently a woman of great dignity, full of warmth and affection, and extremely proud of her only son.

Satyendra grew up in a normal extended family of a loving mother, younger sisters, uncles and aunts and a strict father who commanded more respect than overt love as was customary in families of India. He traveled often with his father on his executive tours of East India Railways in Assam and Northern Bengal. The scenic beauty of Assam and the river Brahmputra were some of his rare memories of childhood. His schooling began at the age of five in schools that were situated close to where they lived, but finally he switched over to the Hindu School, a school of great tradition and distinction in the first decade of the $20^{\text {th }}$ century. From all accounts, Satyendra was recognized as a gifted child by all his teachers. In spite of his weak eyesight since childhood, he was a voracious reader of Bengali, Sanskrit and English literature, well versed in the poetry of Lord Tennyson, Rabindranath Tagore and Kalidasa. His mathematics teacher in the Hindu School recognized him as a genius in mathematics and proclaimed that he would be one day known as another Laplace or Cauchy.

\section{Presidency College, Swadeshi Movement}

By the time he joined the Presidency College in Calcutta in 1909, Bose, despite his natural aptitudes for languages and humanities, had decided to pursue science. That was partly motivated by the prevailing nationalistic sentiment ignited by the partition of Bengal in 1905 . By partitioning Bengal, Lord Curzon, one of the most imperialistic, reactionary viceroys of British India, had intended to curb Bengal's influence on the rising national struggle for independence. Instead this created a furor against the Raj, and initiated a strong swadeshi movement of self-sufficiency, symbolized by the boycott of foreign goods, a public bonfire of 
British mill-textiles, reliance on home spun industries, and street gatherings singing patriotic songs. Rākhi-bandhan, a popular festival in North India in which a sister ties a colored thread around a brother's wrist as a mark of assurance of protection from all sorts of dangers, was converted into a solidarity pledge between all peoples, Hindus and Muslims exchanging rākhis.

Among the young, it generated a strong national awareness and dedication to the service of the country. Talented students like Satyendra Nath thought science, engineering and technology were the ways to lead the country to progress and prosperity. They had the ideals of people like Jagadish Chandra Bose (J.C. Bose) and the noted chemist, Acharya Prafullachandra Ray (P.C. Ray), who had gone abroad and returned home with international recognition and fame. With meager salaries and poorly equipped laboratories they were carrying on original research. They also had the example of Srinivasa Ramanujan orchestrated by the well-known Cambridge mathematician G.H. Hardy.

The year 1909 was remarkable in the history of the Presidency College and in the scientific history of Bengal. The college's entering class included a group of extremely talented students who would make a mark in their own original research in many areas and play a dominant role in the scientific and economic development of free India. The brightest among them were Bose and Meghnad Saha. Saha who was to become a close friend and collaborator in research joined the Presidency College two years later.

United in their nationalistic ideals, the group was a part of overt and clandestine activities in the swadeshi movement. Some of the students risked their careers. Some became members of the National Revolutionary Movement - one of several independence-minded groups in British colonial India - based in the state of Bengal. Upon the outbreak of the First World War, its members began to organize an armed rebellion in India. In that noted politically charged atmosphere, several people, notably Manabendra Nath Roy (1887-1954, popularly known as M.N. Roy) and Abani Mukherjee (1891-1937), left the country to secure arms from Germany and America.

Bose was in contact with Abani Mukharjee directly or indirectly and helped him in many ways. He, however, was under strict orders from his father not to get involved in any activities that might spell the end of his brilliant career. As the eldest son and only son, he was made aware of his responsibilities to the family. He obeyed his father, but remained a strong supporter of those who participated in the Swadeshi movement, helping in whatever way he could, acting as a courier, providing shelter to fugitives from police pursuit, or helping out with money. Throughout his college years he took an active part in running the night schools for the children of working class that came to be known as the Working Men's Institute. He strongly believed in the enlightenment and self-awareness through education of the masses more vital to independence than popular simple slogans like, "Down with the British, down with English education."

\section{Marriage, Career Ups and Downs}

Bose completed his B.Sc. degree in 1913 and his M.Sc. in 1915, securing the first place in both the examinations; Saha took the second place. Both Saha and Bose, mostly self-taught, had 
glimpses of exciting discoveries in modern atomic physics and relativity and had developed a strong passion for theoretical physics. Both, however, faced a bleak situation, with no opportunities for further study and research or any jobs to speak of. In the mean time, when he was only 20 years old and still a student doing M.Sc. Bose married Ushabati, who was the only daughter of a renowned and rich doctor, Jogindranath Ghosh. Bose was not keen on getting married so early, but he could not go against his mother's wishes. Marriage in India at an early age, when still in college, was very common then and remains common now. Bose, however, was exceptional in neither accepting a dowry nor seeking monetary help from his wife's family when faced with difficult financial situations. If he wanted to, he could very well have received support from his father-in-law for a trip abroad for higher studies, a prevalent practice. The couple's first child was born soon after Bose received his M.Sc. degree.

Unemployed both Bose and Saha spent a year, earning what they could from private tutoring. Bose tried to work towards a doctorate degree in mathematics under Ganesh Prasad who had just joined the University of Calcutta. Prasad (1876-1936), a D.Sc. from Allahabad University, used to teach at Queen's College in Banaras before coming to Calcutta. Known to set hard questions that went beyond the expectations of normal students, Prasad had an aura of scholarship and intimidation. Bose failed to establish a rapport with him. Recalling, Bose writes:

The students flocked to him for training in search. They were the best science students of Calcutta University, but they had not fared so well in his exams. But the fault lay with the teachers at Presidency College - at least which is what Ganesh Prasad thought. The young students had to stomach adverse comments about their former teachers, too scared to answer back. After my M.Sc. I too presented myself before Ganesh Prasad who was also my examiner though I had not fared as badly as the others [on Prasad's exam questions]. Dr. Prasad was kind to me at first but I was notorious for plain speaking. I found it difficult to bear his tirade against my teachers. I had dared to counter his adverse criticisms. This infuriated him. He said - you may have done well in the examination but that does not mean you are cut for research. Disappointed I came away. I decided to work on my own. ${ }^{1}$

He also decided to apply for a teaching position when he came across an advertisement by the government of Bihar - a state neighboring Bengal. With letters of recommendation from Principal James and Debendranath Mullick [who had taught at Hooghly, Patna and Presidency Colleges and was President of the Physics and Mathematics section of the Indian Science Congress in 1919], Bose applied for the position but failed to get it because he was over qualified. He also applied for a position at the Alipore Meteorological Office but was turned down for the same reason.

Just as the situation looked bleak, a splendid opportunity presented itself to Bose and Saha. It came from Sir Asutosh Mookerjee, the Vice Chancellor of the University of Calcutta, who was a distinguished mathematician with strong interest in physics. However, having had no 
opportunities for continuing research and advanced studies, he had opted for law and had risen to eminence as the high court judge. With generous financial help from two other lawyers, Taraknath Palit and Rashbehari Ghosh, he established a University College of Science as part of the Calcutta University with emphasis on teaching advanced courses and basic research. It started functioning in 1916. As Bose recounts,

"One of our classmates, Sailen Ghosh, popularly known as 'Mama' [lit. uncle], had done well in physics. He too was without a job. But he was very resourceful. He went up to Sir Asutosh with a suggestion: Why not start teaching subjects in the University that are not taught at Presidency? The logicians had in the meantime thought of various plans for the physics department in the University. But who was going to teach?

One day we were called up by Sir Asutosh. Meghnad, Sailen and I went up the steep stairs to the library, to the special chamber where Sir Asutosh sat. We were naturally meek and submissive and overawed by his august presence. He had heard that the younger generation wanted more modern subjects to be introduced in the University curriculum. He asked, 'What subjects are you competent to teach, boys?

'Sir, we will try our best to teach whatever you want us to.' He smiled. We had only heard of the many new discoveries in physics, most of them made in Germany - new developments and new discoveries. Planck, Einstein, Bohr - we Bengalis had only heard of them. To know more about them one had to read books in German or research journals in other languages. During the war most of these journals did not come to India.

At long last, as the first step to a new career, we were given a special allowance of Rs. 125 per month. Meghnad was assigned to study quantum theory and I had to learn Einstein's relativity theory. We came away committing ourselves to being prepared to teach within a year. But where were we to get the books from? There were some books in English on relativity; we got hold of them. But where could we get hold of the writings of Boltzmann, Kirchhoff, Planck..?"2

Help came again from an unexpected source. Bose knew Dr. P.J. Bruhl, who was teaching engineering physics at Sibpur in the Bengal Engineering College. M.Sc. students from the Presidency College used to do their required "practical work" in his laboratory. Bruhl was from Germany with a doctorate in botany. He had come to Calcutta seeking a warm and sunny climate because of his ill health due to tuberculosis. The scholarship he had to study flora in India was suspended when he got married. He decided to stay in India, switched to physics, and got a job to teach engineering physics.

He had an excellent collection of science books, advanced texts and journals on physics in German including Planck's Theorie de Wärmstrahlung, Laue's Relativitätsprinzip. Bose and Saha could not have asked for more. They borrowed whatever books they could lay their hands on - Planck, Boltzmann, Wilhelm Wien and others. Saha had taken pains to learn German; 
Bose knew French and was taking lessons in German. Together they prepared themselves to teach advanced modern physics and forged a collaboration in research. ${ }^{3}$

In 1919, soon after the war ended and Einstein's theory received worldwide acclamation due to the confirmation of one of its predictions, namely, the deflection of light due to gravitational field, the young self-taught stalwarts took upon themselves the translation of the original papers on special and general relativity. Bose and Saha's book was the first such collection in English. ${ }^{4}$

Satyendra Nath, like other aspiring young scientists, was eager to go abroad to Europe, but he was not fortunate enough for one reason or the other to acquire such an opportunity. Being married was one of his obstacles. His friend and colleague Saha was more enterprising. He was awarded the Doctor of Science degree of Calcutta University and on that basis won a scholarship to go abroad. In the mean time, while teaching thermodynamics and astrophysics, Saha got interested in thermal ionization and developed the celebrated Saha's theory of high temperature ionization and its consequences in astrophysics. The scholarship afforded him the opportunity to work in the laboratories of A. Fowler in London and Herman Walther Nerst in Germany to verify his theory.

In 1921, Bose got an offer of a Readership at a higher salary in the newly established university in Dacca in East Bengal (presently called Dhaka University, that is now in Bangladesh). The Vice Chancellor of the University, P.J. Hartog, was a visionary committed to excellence. He hand-picked Bose, who soon found himself with the task of building a whole new department - including setting up laboratories - to teach advanced courses for B.Sc. honors and M.Sc. students. He taught thermodynamics and Maxwell's theory of electromagnetism. The library was just being replenished with books and journals. And just as his first group of students was graduating in 1923, he received notification that his appointment could not be extended beyond a year. A conflict between the government of India and the provincial Government of Bengal had resulted in the cut-off of funds for the university. Bose became involved in a long struggle with the university to keep his appointment. It was under such troubled circumstances that he wrote his famous paper and sent it for publication in late 1923 or the beginning of 1924 to Philosophical Magazine. Six months later, when the editors of the journal informed him that (regrettably) the referee's report on his paper was negative, he sent his rejected paper to Einstein with an accompanying letter (See Fig. 1), which begins $^{5}$

\section{Respected Sir,}

I have ventured to send you the accompanying article for your perusal and opinion. I am anxious to know what you think of it. You will see that I have tried to deduce the the coefficient $8 \pi v^{2} / \mathrm{c}^{3}$ in Planck's law independent of the classical electrodynamics only assuming that the ultimate elementary regions in the phasespace has the content $h^{3}$. I do not know sufficient German to translate the paper. If you think the paper is worth publishing, I shall be grateful if you arrange for its publication in Zeitscrift für Physik. 


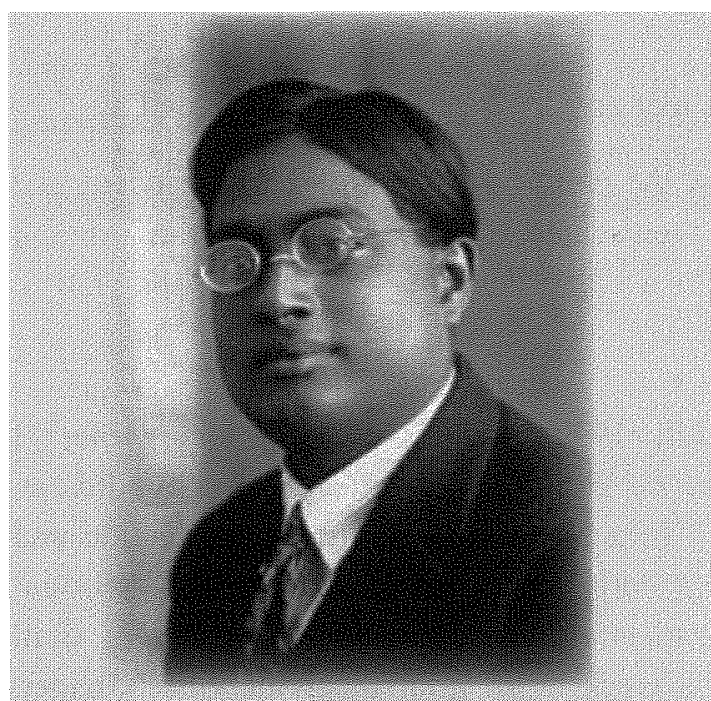

Figure 1. Salyendra Nath Bose in Panis in 1925. It was from Dacca in 1924 that Bose sent Einstein this letter accompanying his manuscript on planck's blackbody radiation law. (Photo courtesy of Falguni Sarkar; letter from ref. 8 .

\section{PHFsies ogpaltunert,

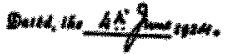

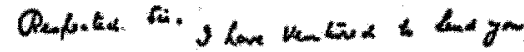

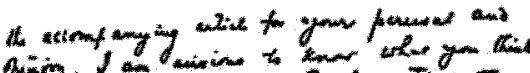

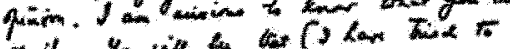

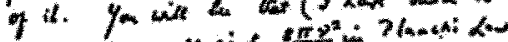

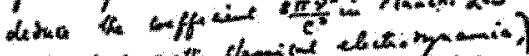

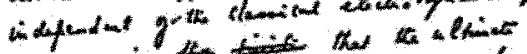

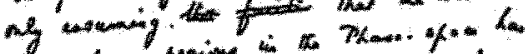

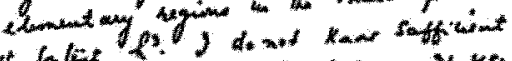

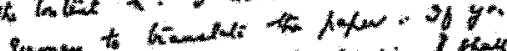

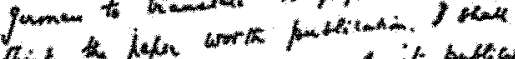

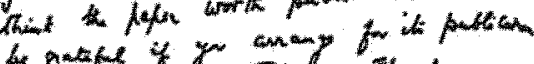

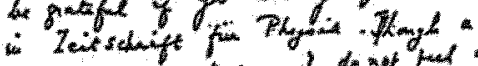

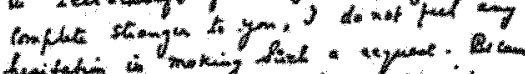

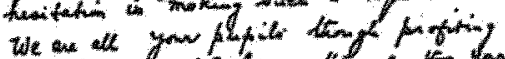

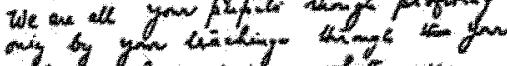

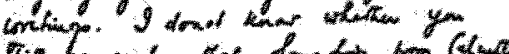

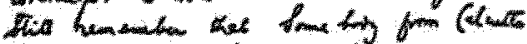

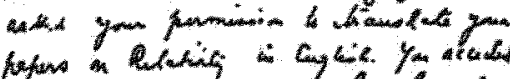

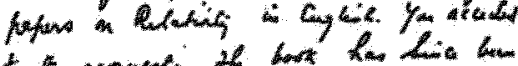

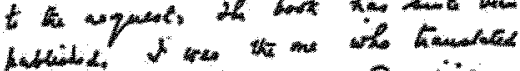

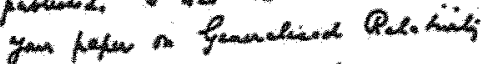

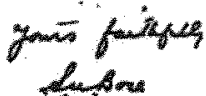

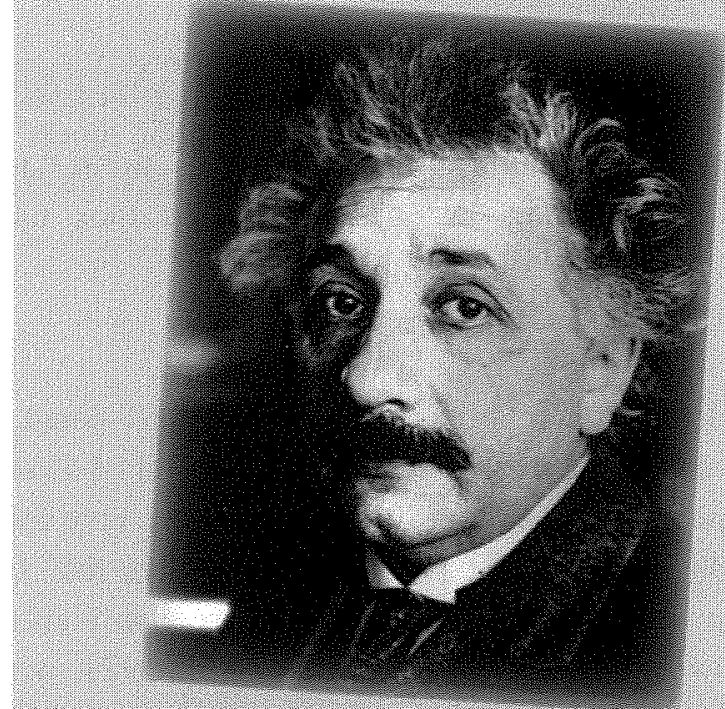

Figure 2. In July 1924, Albert Linstein sent S.N. Bose a postcard (len) lhat accepted Bose's paper on radiation statistics and acknowledged its importance. (Card from ref: 1; $1920 \mathrm{~s}$ photo of Einstein courtesy of A IP Imilio Segré Visual Arehives.)

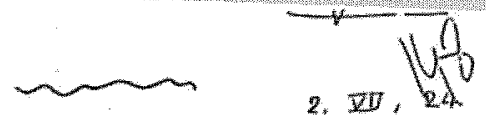

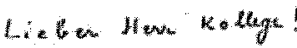

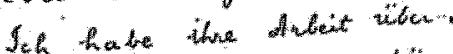

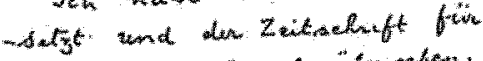

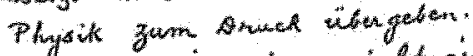

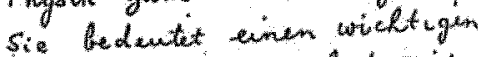
Toutsobrilt wand hat mive Detur gut gefallen. The

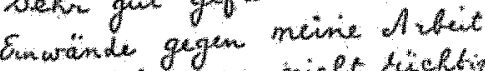

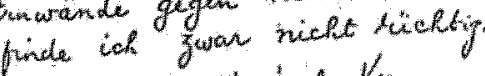

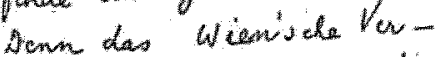

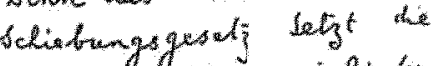

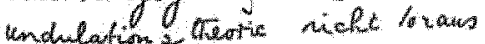

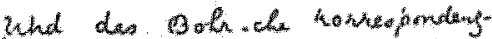

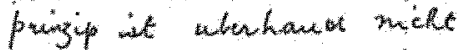

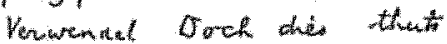

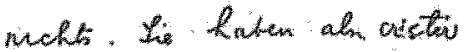

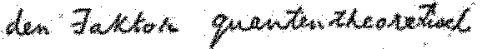

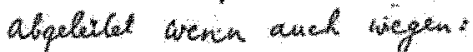

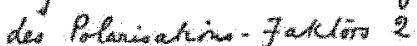

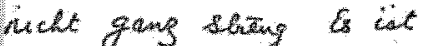

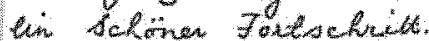

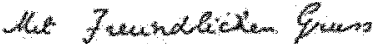
(c) 16 E E 
Bose goes on:

Though a complete stranger to you, I do not feel any hesitation in making such a request. Because we are all your pupils though profiting only by your teachings through your writings.

Yours Faithfully,

S.N. Bose

Einstein's reply came in a postcard dated 2 July 1924 (Fig. 2) in which he wrote, "I have translated your paper and given it to Zeitscrift für Physik for publication. It signifies an important step forward and pleases me very much." In a note appended to his translation and published with the paper, Einstein says that Bose's derivation "appears to me an important step forward. The method used here also yields the quantum theory of an ideal gas, as I shall show elsewhere." Indeed, on 10 July 1924, within a week or so after receiving Bose's paper, Einstein presented his own paper to the Prussian academy. Titled "On the Quantum Theory of Monoatomic Gas," it was an extension of Bose's work. He followed up that paper with two more in 1925, the second of which is well known for its prediction of a possible new state of matter whose existence took 70 additional years to demonstrate - the Bose-Einstein condensate.

Bose's successful derivation of Planck's law and Einstein's recognition of its importance is one of the most exciting episodes of the $20^{\text {th }}$ century physics. It has all the twists and turns and ironies of failed attempts on the part of some of the great physicists of the period and the success of a relatively unknown young man from Dacca University in East Bengal. It involved a great struggle on many profound philosophical issues associated with the fundamental nature of matter and radiation. I will not dwell here on this history and its subsequent developments since it is the subject matter of several papers in this volume. Returning to Bose's life, Einstein's 2 July postcard had a tremendous impact on his life and career. It was influential enough for him to obtain a two-year study leave in Europe. He had applied for such a fellowship in January, but he had not received any response. But as soon as the Vice Chancellor saw the postcard, the problem was solved. As Bose says

That little thing [Einstein's postcard] gave me a sort of passport for the study leave study leave for two years with a good stipend, a separation allowance for the family, sumptuous travel allowance with a round trip fare. ${ }^{6}$

He also got a visa from the German consulate just by showing them Einstein's postcard. No fee required! He left for Europe in early September aboard a steamer of the Lyod Triestino Line and arrived in Paris in 18 October 1924.

\section{Paris and Berlin}

Before he left for Paris, on 15 June, only eleven days after he had sent his first paper, Bose sent a second paper to Einstein with the following letter: 
I send herewith another paper of mine for your kind perusal and opinion. I hope my first paper has reached your hand. The result to which I have arrived seems rather important (to me at any rate). You will see that I have dealt with the problem of thermal equilibrium between Radiation and Matter in a different way, and arrived at a different law for the probability of the elementary processes [presumably, different from the law proposed in Einstein and Ehrenfest 1923], which seems to have simplicity in its favor. I have ventured to send you the typewritten paper in English; it being beyond me to express myself in German (which will be intelligible to you). I shall be glad [to (crossed out in letter)] if its publication in Zeit. für Physik or any other German journal can be managed. I myself know not how to manage it. In any case, I shall be grateful if you express any opinion on the papers, and send it to me at the above address.

Yours Truly,

S.N. Bose

(Einstein Archive, Doc. 6-128)

In Paris, Bose stayed in a pension at 17 Rue du Sommerard in a building that was the home of India Association, a meeting place for students from India. The association helped visitors, students, and student activists involved in anti-British national movement with accommodations and other needs. Bose knew several of them from Calcutta and spent the first few days' sightseeing in Paris.

During his study leave Bose was expected to learn something new in the great laboratories of Europe to take back home. The Vice Chancellor Hartog had written to Earnest Rutherford and William Braggs, whom he knew personally, introducing Bose and requesting an opportunity for Bose to work in their laboratories. Rutherford had replied regretfully that he could not because of lack of space. Bragg was non-committal. Paris offered the possibility of working in the X-ray and crystallography laboratories of Maurice de Broglie or the institute where Madame Curie worked on radioactivity. So Bose stayed on in Paris before venturing to go to Berlin to meet Einstein.

Bose came to know Paul Langevin who had read his paper and so received him warmly. When he expressed interest in working in radioactivity at the Institute of Madame Curie, Langevin wrote a letter of introduction with which Bose went to see her. Madame Curie greeted him affectionately and said that there was no way she could disregard a recommendation from a person like Langevin. Bose would certainly get an opportunity to work in her laboratory, but not right then. Speaking in chaste English for about ten minutes, she asked Bose to get to know the French language first to be able to work in her laboratory. Bose had no opportunity to tell her that he knew French, he had been at it for ten years. ${ }^{7}$ Bose came away resigned to wait, and chose to work in de Broglie's X-ray laboratory. Later though, at the beginning of the following year, he was granted facilities to work in her Institute, but Bose does not mention any further contact with Madame Curie. 
As mentioned earlier, around the same time Bose sent his first paper to Einstein, he had also sent a second paper from Dacca to Einstein. In March 1924, M.N. Saha paid a friendly visit to Dacca and stayed with Bose. He also brought attention to new attempts at the derivation of Planck's law due to Wolfgang Pauli, and Einstein and Paul Ehrenfest. This set Bose thinking about the interaction between radiation and ordinary matter and led to the second paper he sent to Einstein. On 26 October, shortly after his arrival, he wrote to Einstein:

\section{Dear Master,}

My heartfelt gratitude for taking the trouble of translating the paper yourself and publishing it. I just saw it in print before I left India. I have sent you about the middle of June a second paper entitled "Thermal Equilibrium in the Radiation Field in the presence of Matter."

I am rather anxious to know your opinion about it, as I think it to be rather important. I don't know whether it will be possible also to have this paper published in Zeit. für. Physik. I have been granted study leave by my University for 2 years. I have arrived just a week ago in Paris. I don't know whether it will be possible for me to work with you in Germany. I will be glad however if you grant me the permission to work under you, for it will mean for me the realisation of a long-cherished hope.

I shall wait for your decision as well as your opinion of my second paper here in Paris. If the second paper has not reached you by any chance, please let me know, I shall send you the copy I have with me.

With respect

Yours Sincerely,

S.N. Bose (Prof.) (26 October 1924, Einstein Archive, DOC. 6-129)

Bose's second paper begins with a critical review of the previous derivations (those of Einstein, Pauli, and the generalization of Pauli by Einstein and Ehrenfest) that, according to him, contained special assumptions that were unnecessary. For Bose, the methods of statistical mechanics alone were sufficient to study the thermal equilibrium of radiation and matter independent of any specific mechanism of the elementary processes on which the energy exchange depended. Bose had obtained a general relation, which was valid for all special assumptions made by the previous authors about the elementary processes and their probabilities.

Einstein's reply came on 3 November,

Most esteemed colleague!

Friendly thanks for your letter of 26.10. I am happy to have the opportunity to meet you personally. Your papers have appeared already some time ago; 
unfortunately the offprints were sent to me instead of you. You can have them any time. I am not in agreement with your elementary law of probability for the interaction between radiation and matter, and have given the reason in a note that appeared together with your article. To wit, your law is not compatible with the following two conditions:

1. The coefficient of absorption is independent of the density of the radiation.

2. The behavior of an oscillator in a radiation field must result from the statistical laws as a limiting case.

We can discuss this in more detail when you come here.

With friendly greetings

Yours

(Einstein Archive, DOC. 6-130)

Bose took some time to reply to Einstein. He wrote on $27^{\text {th }}$ January from his Paris residence,

Respected Master,

I received your kind note of 3 rd November in which you mentioned your objections against the elementary law of probability. I have been thinking about your objections all along and so did not answer immediately. It seems to me there is a way out of this difficulty, and I have written down my ideas in the form of a paper which I send under a separate cover. It seems that the hypothesis of negative Einstrahlung stands, which, as you have yourself expressed, reflects the classical behaviour of a resonator in a fluctuating field. But the additional hypothesis of a spontaneous change, independent of the state of the field, seems to me not necessary. I have tried to look at the radiation field from a new standpoint and have sought to separate propagation of Quantum of energy from the propagation of electro-magnetic influence. I seem to feel vaguely that some such separations are necessary if Quantum theory is to be brought in line with Generalised Relativity Theory.

The views about the radiation-field, which I have ventured to put forward, seem to be very much like what Bohr has recently expressed in May Phil. Mag. 1924. But it is only a guess, as I cannot say honestly to have exactly understood all he means to say, about virtual fields and virtual oscillators.

I am rather anxious to know your opinion about it. I have shown it to Professor Langevin here and he seems to think it is interesting and worth publishing.

I cannot exactly express how grateful I feel for your encouragement and the interest you have taken in my papers. Your first postcard came at a critical 
moment, and it has more than any other made this sojourn to Europe possible for me. I am thinking of going to Berlin at the end of this winter, where I hope to have your inestimable help and guidance.

Yours Sincerely,

S.N. Bose

(Einstein Archive, DOC. 6-131)

Bose never published this third paper, and no trace of it exists in the Hebrew University's Albert Einstein Archives. It is regrettable that, either because of Einstein's critical remarks or because of the advent of new quantum mechanics, Bose's second paper has also received little attention.

Fortunately, Partha Ghose, has provided an in-depth analysis of both these papers. ${ }^{8}$ Recalling a long conversation he had with Bose in December 1973 or January 1974, Ghose writes that Bose had his own approach to quantum theory based on his views about the interconnectedness of spontaneous and induced emissions, which formed the subject matter of his second and third papers. He did not agree with Einstein's proposal to treat them as independent physical processes. Stationary states in atoms have zero widths both in the old and the new quantum theories and therefore have infinite life-times, whereas in reality they do decay and jump down to lower energy states with a finite life-time.

What is the origin of these finite widths? In Bose's view, they are a consequence of the interaction between atom and environment, as he attempted to show in his second and third papers. But Einstein did not agree and dismissed his views with the remark that in a world consisting of a single excited hydrogen atom and nothing else, the atom would obviously emit a photon and come down to its ground state! Einstein did not explain what would excite an atom in such a world! Bose was very disappointed by this simply because the world does have much more than a single hydrogen atom, and inevitably every atom does have an environment. What further disappointed him was that later on, stationary states were seen to acquire finite widths in Dirac's Quantum Electrodynamics through interactions with the vacuum, which was equivalent to an environmental interaction, and this came to be accepted even though Quantum Electrodynamics led to unacceptable divergences. Presumably Bose's way of solving the problem did not produce divergences, but this is something that Ghose didn't have the opportunity to discuss further, because it was apparently quite late by then and it was time for his lunch. He was feeling quite exhausted and weak, and asked Ghose to come back another day. Ghose went back to Santiniketan where he was working, and before he could go back to him, he passed away in February 1974.

Ghose recalls two other comments Bose made that are significant. For him it was clear that the world was basically non-linear as was evident from general relativity. A linear theory like the quantum theory could never be the real story. He implies this in his letter to Einstein (...if quantum theory is to be brought in line with Generalized Relativity). Also, implied in his second paper, the existence of Bohr-like stationary states and the vanishing of cross-sections at certain energies (Ramsauer effect) were evidence for "no interaction" (absence of radiation from stationary states) where classical theory leads one to expect such interactions. ${ }^{9}$ 
After spending a year in Paris, Bose went to Berlin in October 1927 and on his arrival wrote to Einstein,

Dear Sir,

I have just arrived in Berlin, and am very anxious to see you. I shall be glad if you kindly write when it will be convenient for you.

Yours Sincerely,

S.N. Bose

(8 October, 1925, Einstein Archive, Doc. 6-132)

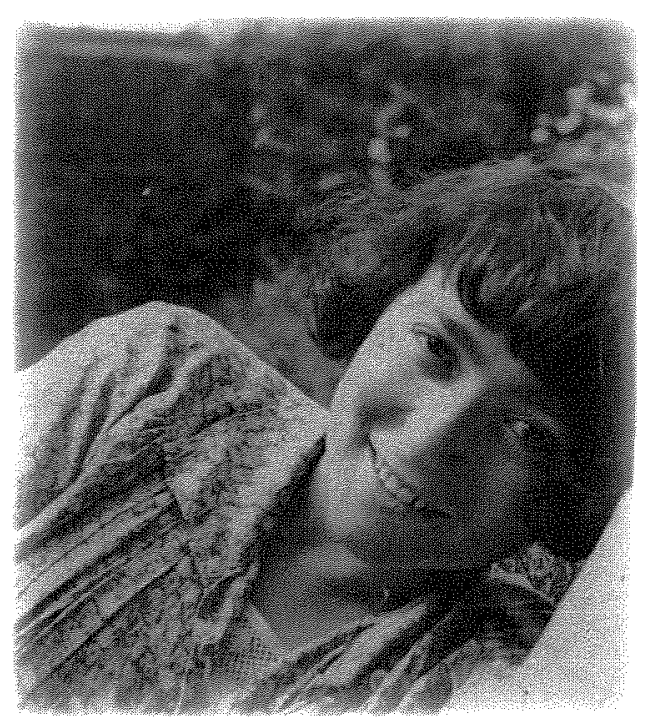

Jacqueline Zadoc-Kahn (Courtesy of Etienne Eisenmann.)

They met and Einstein introduced him to several prominent physicists including Fritz Haber, Otto Hahn, Lise Meitner and Walter Gordon. It was an exciting time in Berlin. It was the beginning of the New Quantum Mechanics. As Bose describes in a letter to Jacqueline Zadoc-Kahn, a young student he met while attending Langevin's lectures at the Collège de France ${ }^{10}$

"Everybody (every physicist) seems to be quite excited in Berlin the ways things have been on with Physics. First on the $28^{\text {th }}$ October Heisenberg spoke in the colloquium about his theory, then, in the last colloquium, there was a long lecture on the recent hypothesis of the spinning electron (perhaps you have heard of it). Everybody is quite bewildered and there is going to be very soon a discussion of Schrödinger's papers. Einstein seems quite excited about it; the other day coming from the colloquium, we found him jumping, in the same compartment, where we were, and forthwith he began to talk excitedly about the things we have just heard. He has to admit that it seems a tremendous thing, considering the lot of things which these new theories correlate and explain, but he is very much troubled by the unreasonableness of it all. We were all silent, but he talked almost all the time; unconscious of the interest and wonder that he is exciting in the mind of the passengers.

According to Mehra and Rechenberg, Einstein proposed two problems to Bose to work on: first, the question whether the new statistics implied a novel type of interaction between the light quanta," and second, as described by Bose himself: "He wanted me to try to see what the statistics of light-quanta and the transition probabilities of radiation would look like in the 
new theory." Apparently Bose made no progress on either of the two problems. It was probably because, as John Stachel says, "like many contemporaries who had mastered the old quantum theory, he [Bose] seems never to have been comfortable with the new quantum mechanics."12

Instead Bose spent sometime at the Kaiser Wilhelm Institute, Berlin-Dahlem in the laboratories of Hermann Mark. In an interview in 1974, Mark recalls his meeting Bose at a seminar Bose gave in Berlin in 1925-1926. "I don't recall whether he gave the seminar in English or German," says Mark. "But I think he gave it in German because he was fluent in German. Usually after the presentation, Laue would get up and say, 'alright fine, this was nice, and is there any question?' Then there would be a lengthy discussion on what the issue was. And in this case Laue said immediately, I am not sufficiently familiar with the topic and I would like to ask Prof. Einstein to comment. Then Einstein said, 'WelI, I think this is one of the most worthwhile works of the last few years.' He talked about it and asked a few questions and Bose answered the questions and then Nernst asked a few questions. In other words it was a very sensational event on that day. The discussion on this specific seminar took a few hours! That was the first time I saw him and liked him. Then of course Karman, Leo Szilard, Eugene Wigner also asked questions. We were young and he was young - so we quickly became friends and we invited him to come to the Kaiser Wilhelm Institute in Dahlem and give us the same seminar to continue the discussion and so he came out a few weeks later and we had there a seminar." 13

Bose liked the people and found the atmosphere at Kaiser Wilhelm Institute more agreeable and livelier than at the University of Berlin. He moved to a new apartment not far from the Institute and became a regular visitor. He became interested in Hermann and his collaborators' research on X-ray structure, study of crystals of metallic materials and the way they were formed. As Hermann recalls, "he always asked sharp questions and kept us thinking. You know, the most real impression we all had was when Bose was facing some new area of scientific endeavor or activity, he just sat there, listened for a while and he had a fantastic grasp over the fundamentals of the specific work and then he would ask questions and he would ask extremely relevant - not only intelligent - questions, he would ask questions which were piercing and pointing into future developments." 14

The experimentalists had a great deal of fun listening to discussions about the new statistics between Bose, Eugene Wigner and Leo Szillard. The discussions would last "hours and hours," ending up finally in the small apartment of Mark and his wife Mia at the Institute for coffee or tea and refreshments. According to Mark, Bose was always good-humored, full of good jokes, loved singing German songs, and would frequently get up in parties and conduct. Before Bose was to depart for India, Mark invited him to Vienna for a visit with his parents and his son, and took him to the university to meet the theoretical physicists that included Erwin Schroedinger, Thirring and Flamm. Bose was invited to give a seminar at the university.

Bose also made frequent visits to 5 Heberland Strasse, the flat where Einstein lived. However, there is no record of their scientific conversations or of their differences concerning Bose's second and third papers. Bose never refers to these matters in his rare autobiographical sketches and articles on Einstein, although they seemed to have had extended discussions about matters outside physics. Bose, for instance, recalls an "interesting conversation" he had with him on one such occasion. It was the time in India when strong movements were going on 
to oust the British. The revolutionaries, on the one hand, were making futile attempts to drive out the British by violent armed struggle; on the other hand, the Congress party under the leadership of Mahatma Gandhi was advocating non-violent, non-co-operation ways to achieve the goal of independence. All this was confusing and strange to Einstein. Bose writes: ${ }^{15}$

He confided to me "I think Englishmen are better than other Western colonial nations, and I feel that they are by far better than the French and the Dutch. You should not be surprised at a German like me praising the English (after the World War). Now, tell me do you really want that the British should quit your country? I said, "Of course, we all want to determine our own destinies." He was not quite convinced. He raised a hypothetical question. He said, "Suppose, there was a button near you and all the Englishmen would quit India if you were to press it. So, would you press that button?" I smiled and said, "If God were to grant me such an opportunity, I would not hesitate even for a moment to press it. "Really," he said and kept quiet for a while.

It was common knowledge that after the World War I, the Jews had an opportunity to establish a new State in the land of their ancestors and a new University was set up in Jerusalem. Bose knew that Einstein had taken the trouble to go and deliver an address at this new obscure university. The new State was under the British domination. Just as in India, British were playing divide and rule policy, playing the Jews against the Arabs. So Bose, known for his outspokeness, asked Einstein

Well, why do you Jews then want to establish a new Israeli state? Even you seem to be fairly inclined in its favour. He said, "I have, of course, I now understand what you are saying — it is an emotional matter and cannot be explained by logic."

\section{Professor in Dacca}

In the middle of 1926 , Bose returned from Germany to his university. He had completed the two years of study leave. While he was abroad, a professorship position was announced. He applied for the position with a letter of recommendation from Einstein that said

The recent works of Mr. S.N. Bose, especially his theory of radiation equilibrium, signify in my opinion important and enduring progress of the physical theory. Also in personal discussion with Mr. Bose, I got the impression that he is a man of unusual gift and depth, from whom science has much to expect. He has also at his command an extensive knowledge and certain ability in our science. As a university teacher he will certainly develop a successful prosperous activity.

Einstein's letter and those of Langevin, Maurice de Broglie and Hermann Mark were not enough to make Bose the first choice for the position. He had no formal doctorate degree! Mostly as a formality, the position was offered to D.M. Bose, who was happily settled at the 
Calcutta University. Bose had to wait a year until D.M. Bose declined the offer. He was then appointed as Professor and Head of the Department of Physics. He also became the Dean of Science the same year.

Since his study leave had been supported by the university, Bose felt an obligation to do something in return. His two-year stay in Europe had been in many ways a turning point in his career as a teacher. He had realized the importance of experimental research in the advancement of science and had spent a year in France getting first-hand experience working in the laboratories of de Broglie, Madame Curie, and Hermann Mark. So, on his return he occupied himself with experimental work, designing and building his own equipment to set up an X-ray crystallography laboratory. As Head of the Department, he also began to redirect the physics department towards experimental and theoretical research in other areas, setting up laboratories and library facilities. Soon it became the center of research in areas that included X-ray spectroscopy, X-ray diffraction, magnetic properties of matter, optical spectroscopy including Raman Spectra, and wireless.

Scientifically, he devoted himself almost exclusively to teaching and guiding research. "He would come to the Department around $7 \mathrm{a} . \mathrm{m}$. and be there until late in the evenings except for a short lunch break," writes Partha Ghose. "Whenever he was not taking a class or attending a meeting, there would be a continuous stream of visitors to his room, and Satyendranath would get involved with their academic problems for hours. It could be any branch of Physics, Chemistry, History, hieroglyphics or indeed any other subject under the sun. He was engaged in creating a culture of intellectual discourse."16

It was a vibrant life at Dacca both scientifically and culturally. Noted scholars and writers visited the university regularly. The University had made great strides in providing higher education to Muslim students, whose number increased from 160 in 1921 to 600 in 1941. The residence halls for Hindu students that were originally run on caste lines, with separate dining halls for Brahmins and non-Brahmins were slowly being integrated. However, at the same time, during the years 1926-1941, the political situation in the country was beginning to disturb the academic atmosphere. The more peaceful Dacca of the early 1920s began to witness communal riots, famine and the war.

The partition of Bengal in 1905 had created a new Muslim-majority province of Eastern Bengal and Assam with Dacca as the provincial capital, and the Muslim population felt liberated from the political as well as the economic domination of Calcutta's Hindu landowners and lawyers. While this situation created a strong nationalist movement against the British, it also created a separatist Muslim political consciousness and demands for the safeguard of their rights as a minority community. It also played well into the hands of the British government to sow the seeds of division. With the British Government's support and encouragement, the All India Muslim League was formed in 1906. The Dacca University contributed in its own way to the development of an educated Muslim middle class that did not exist before. Gradually, this middle class, imbued with a spirit of Muslim cultural tradition, identified itself with the objective of the Muslim league, demanding the creation of a separate Muslim State. It became a seat of communal disharmony and violent disturbances. 
As the Second World War drew close in 1945, the increased communal tensions, riots and violence, agonized Bose. It became difficult to pursue his scientific and intellectual pursuits. Earlier in 1938, he had received an offer of a position from Calcutta University that he had declined. But in 1945, due to the sudden death of Bidhu Bhusan Ray, the prestigious Khaira chair was lying vacant. And when he was offered this position, he accepted it willingly and returned to his alma mater.

\section{Khaira Professor in Calcutta}

During the quarter of century of Bose's absence, Calcutta University had undergone tremendous changes. When he had left for Dacca, the physics department was in its infancy with scarce resources for research that had led Saha to leave Calcutta and go to Allahabad University. He had returned to Calcutta in 1938 with his research interests focused on nuclear physics, hoping to establish an Institute for Nuclear Research. Sir C.V. Raman, India's first Nobel Laureate in physics, for his classic experiments on light scattering and the discovery that came to be known as Raman Effect ${ }^{17}$ had left Calcutta for Bangalore, but his legacy had persisted. Work in optical scattering and Raman spectra had continued at the laboratories of the Indian Association for the Cultivation of Science (IACS). Raman's researches in acoustics were continued at the University Science College Campus. Researches in other fields had also flourished. D.M. Bose, who succeeded Raman as Palit Professor, was well known for his work in magnetism and atomic physics. S.K Mitra had pioneered work on radio and wireless. Bidhu Bhusan Ray, the preceding Khaira professor, whose untimely death had left the chair open for Bose, had set up an X-ray laboratory with an active group of research workers. In 1945, not only in the physics department, but in almost all departments, the faculty of the University College of Science and Technology had distinguished colleagues.

For Bose, it was a happy homecoming. The faculty and students of the University College extended him a warm welcome. He brought new life, his characteristic openness and informality with students, and his wide ranging interests. Soon a group of brilliant students formed research groups around him, working in the X-ray laboratory. Unfortunately for Bose, shortly thereafter, Calcutta became engulfed in communal violence on an unprecedented scale. Thousands of Hindus and Muslims were slaughtered in a three-day rampage in what has come to be known as "The great Calcutta killing of August 1946," an infamous, tragic episode in India's history. The University College of Science and Technology stood right in the midst of a sensitive area and was heavily affected. Some of its students living in nearby residence halls were brutally murdered. With British army personnel housed within the campus, academic life came to a standstill for sometime, although limited research activities continued. The following year, on 15 August, 1947, India gained its long awaited Independence, but with the country divided, Bengal and Punjab partitioned to create two disjointed East and West Pakistan. More bloodshed and an influx of refugees followed. 


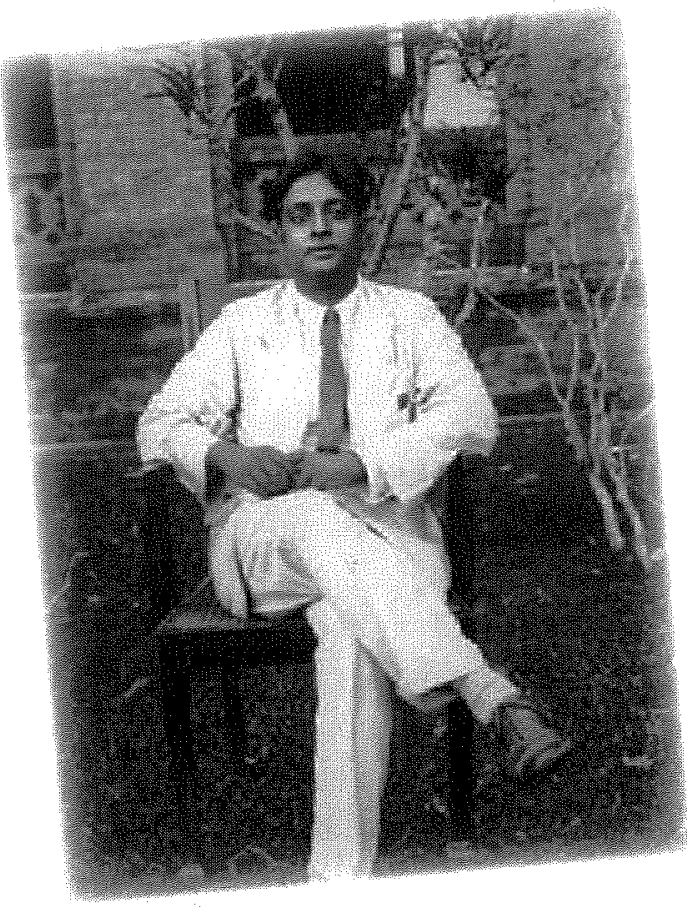

Bose at Dhaka University c.1930s.

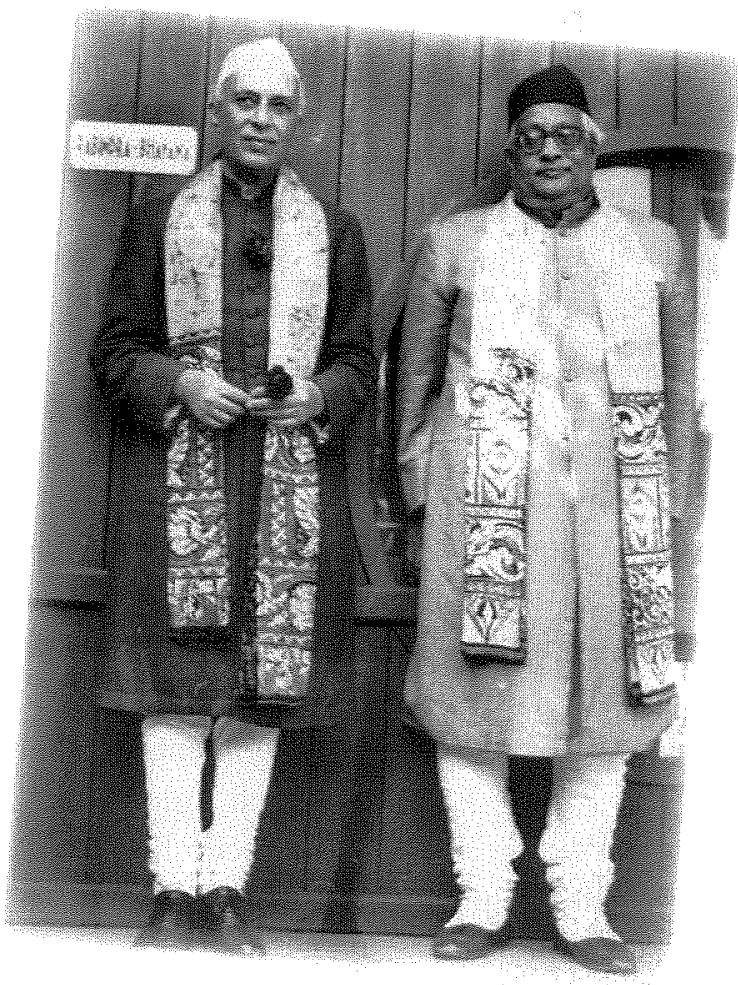

National Professor S.N. Bose with Prime Minister Jawaharlal Nehru (1).

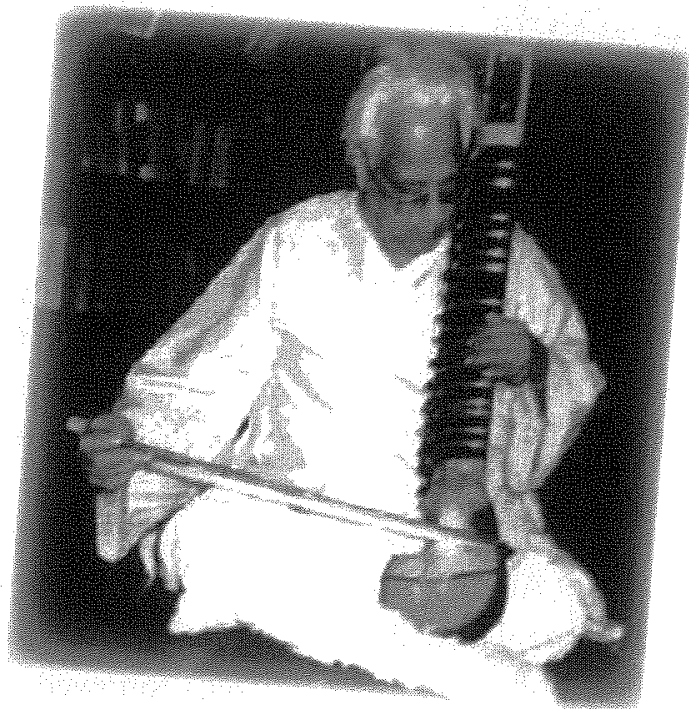

A renaissance man, S.N Bose is seen here playing esraj. He also played flute, and even composed a raga. (Courtesy of Falguni Sarkar.) 


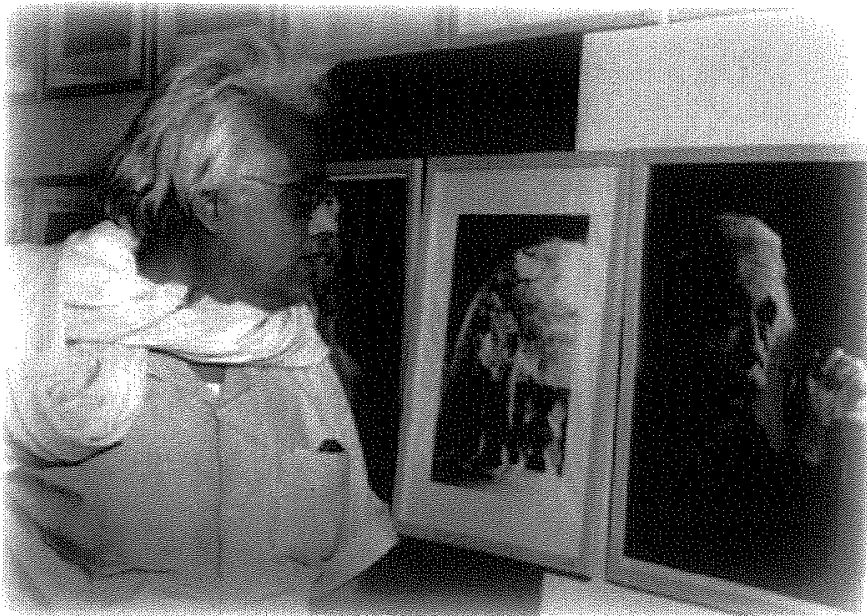

S.N. Bose in 1953. (Courtesy of Etienne Eisenmann.)

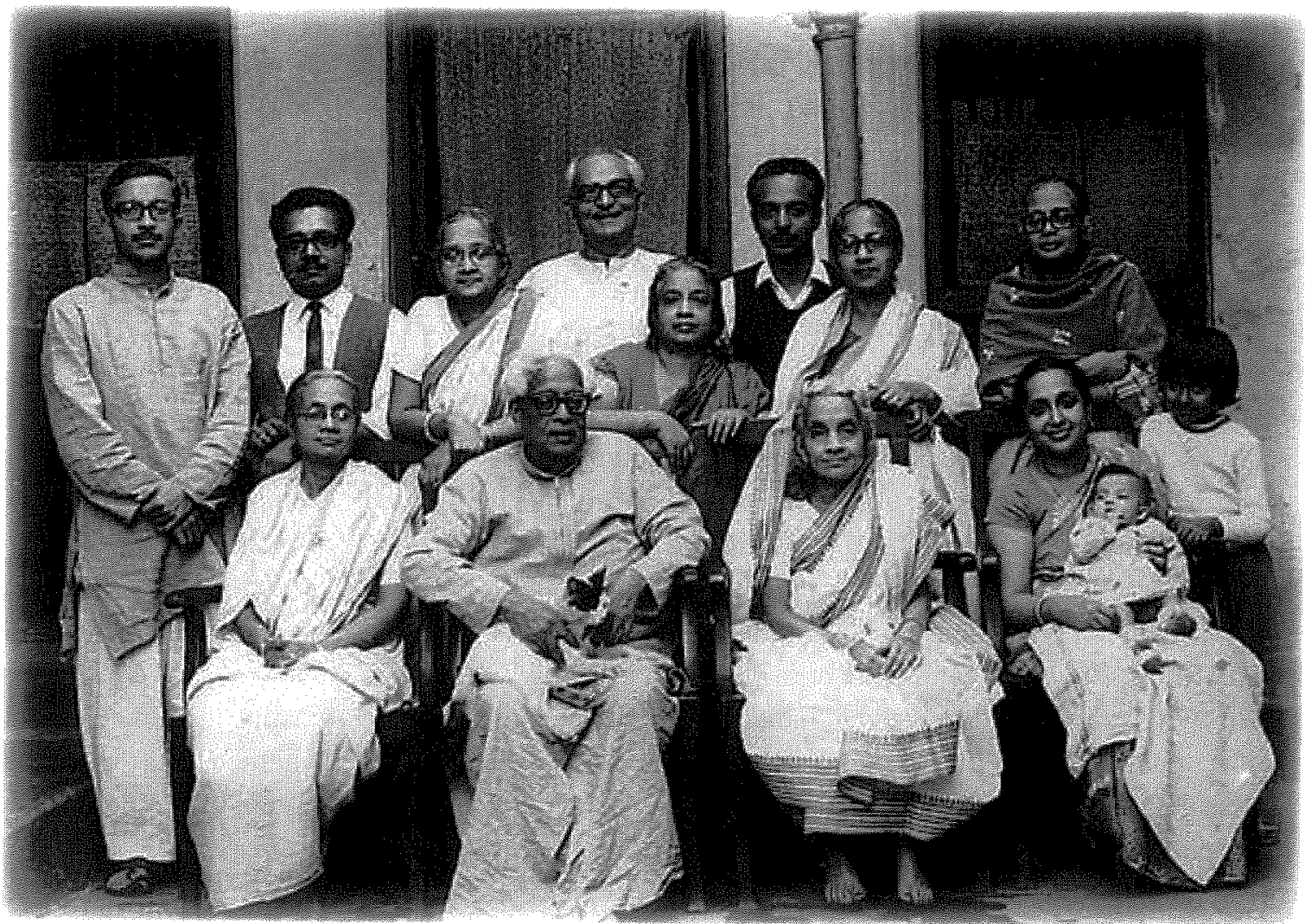

Bose (seated 2nd from left) and his family c.1960s. 


\section{Aftermath, Independent India}

All this had a profound effect on Bose. He felt betrayed and disillusioned. India was free but mutilated. Part of Bengal where he had spent twenty-five best years of his life was now a foreign territory. He agonized, he did what he could to help anyone that needed help. It was another turning point in his life. He no longer could live isolated in the ivory tower of intellectual pursuits. He had to face the new challenge to face social realities. Independence also opened up new opportunities to serve the country at large.

Fortunately for India, the first Prime Minister after Independence, Jawaharlal Nehru, was a strong advocate of a strong national effort to utilize science and technology for the upliftment of Indian masses. "It was science alone," he wrote in Discovery of India, "that could solve the problems of hunger and poverty, of insanitation and illiteracy, of superstition and deadening custom and tradition, of vast resources running to waste, of a rich country inhabited by poor people." Long before Independence, in 1939, Nehru was instrumental in establishing a National Planning Committee under the auspices of the Indian National Congress. A committee for Science and Technology was a part of the National Planning Committee, which after Independence became the full pledged Council of Scientific and Industrial Research with the mission of establishing National Research Laboratories, Institutes of Technology and so on. Nehru called upon all the prominent scientists and intellectuals to participate in the new frontiers that Independence had opened. Bose, along with his colleagues, became an adviser to the Council and contributed his share in shaping the future of science in India.

During all these upheavals, work at the Khaira laboratory continued under Bose's guidance. Since the X-ray laboratory was not equipped for crystallography research, Bose and his students constructed a number of precision cameras such as a Weissenberg camera, ${ }^{18}$ a differential thermal analyzer, a micro-focus X-ray tube, a special type of powder camera for clay analysis, and a fully automatic scanning spectrophotometer for thermo-luminescence studies. As in Dacca, he discouraged readymade, imported equipment, instead insisting every student design his or her own equipment, set up instruments from locally available materials and construct them with the help of local technicians in the laboratory. Soon new research areas opened up in many directions including both pure and applied fields. Professors and students in applied mathematics were frequent visitors with problems to be solved or to just have a stimulating conversation. His office was open to any one, to converse on any subject.

Bose was the President of the Indian Physical Society (1945-1948), and the President of the National Institute of Science (1948-1950). He was nominated a member of the Rajya Sabha, the upper chamber of the national parliament in 1954 and honored with the title Padma Vibhusan. He remained a member until he resigned in 1959. During the years 1947-1955, he was a host to a number of foreign visitors that included P.A.M. Dirac and J.D. Bernal. Dirac was apparently surprised Bose was not a FRS, a Fellow of the Royal Society of London. This honor came in 1958, twenty-four years after his revolutionary discovery. ${ }^{19}$ 


\section{Travels Abroad}

During the fifties, Bose made several trips to Europe, the first in 1951, twenty-six years after his first visit. He went to Paris at the invitation of UNESCO. Now that India was independent, he felt free to go to England and spent a week in London on his return trip to Calcutta. While there, he reconnected with many old acquaintances. In Paris he met Jacqueline, the young student he had met in 1924-1925 and had become close friends. She was married to Jacques Eisenmann, an engineer in the civil service and had a daughter and two sons. The war had interrupted her research career. She had volunteered to work in a laboratory of the Air Ministry till 1940. When Bose met her and her family, she was working in the documentation service of a professional organization called the Institut Francais du Caoutchouc. ${ }^{20}$ It was a moving experience for both, as he writes from London on $22^{\text {nd }}$ June, 1951,

Dear Jacqueline,

It was almost a mystic experience to see you, and hear your sweet voice and be near to you after so many years: It has filled me with bliss, and I am deeply grateful to my destiny.

Years have elapsed with any news, and I had almost despaired of ever meeting you again in life: There was also a foolish fear, that under the relentless law of change with time it was hopeless to wish to recover in reality what we cherish in memory draped with cobweb of imagination. How all fears have melted away at your first sight!

I am in London and shall stay here for about a week more, and then I go back to Calcutta:

Hope you will now write again

Yours Affectionately,

Bose

In 1953, Bose was invited to attend the World Congress for General Disarmament and Peace at Budapest. The following year he represented India at the International Crystallography Conference in Paris. He returned to Paris again in 1955, this time at the invitation of the Council of National Scientific Research of France. It was the $50^{\text {th }}$ anniversary of Einstein's "miraculous" year during which he published five papers that revolutionized the world of physics. A conference was to take place in July in Bern, Switzerland, the birthplace of Einstein's discoveries and Einstein himself was expected to attend. Bose, who had tried unsuccessfully to visit the United States and meet Einstein, was eager to attend the conference at Bern. He was also looking forward to the opportunity to discuss his own miraculous output of five papers on the Unified Theory that Einstein was occupied with. At least four of these papers were written within a span of one year (1953). Unfortunately, Einstein's death in April of that year led to the cancellation of that meeting. The following year Bose traveled 
to England for the Annual Meeting of the British Association for the Advancement of Science. He went again two years later to attend the Royal Society Meeting where he was elected a Fellow.

\section{Vice Chancellor at Visva-Bharati}

In 1956, at the age of sixty-two, Bose retired from the post of the Khaira professor and became the Vice Chancellor of Visva-Bharati, situated in Santiniketan, a small town, 180 kilometers north of Kolkata. It was here in Santiniketan (abode of peace), on an almost bare tract of land, Rabindranath Tagore had founded a school in 1901, and twenty years later Visva-Bharati, a university. In 1951, ten years after his death, the central government of India took over the institutions, which continues to run them. The school he founded, in rebellion against the mainstream strict, repetitive, parrot-like learning of his childhood, was based on the philosophy that learning becomes both effective and enjoyable when it is in natural environment without superficial barriers between teachers and students. The school that started with only five students, often referred to as Ashram system, soon became a renowned institution offering primary and secondary education. Sixteen years later, when relaxing on the beach in Santa Barbara, California, he conceived of a university, as he wrote to his son Rathindranath on 11 October 1911:21

I have in mind to make Shantiniketan the connecting thread between India and the world. I have to found a world center for the study of humanity there. The days of petty nationalism are numbered - let the first step towards universal union occur in the fields of Bolpur. I want to make that place somewhere beyond the limits of nation and geography.

The foundation stone of his dream university to be called "Visva-Bharati" was laid on 22 December 1918 and exactly three years later it was inaugurated. He had traveled extensively in India, Europe and USA to raise funds and used his own Nobel Prize money to start the university. For Tagore, "Visva-Bharati" represented "India where she has her wealth of mind which is for all." He hoped Santiniketan would be a meeting place for western and Asian scholars, a place where the ancient learning would be rejuvenated through contact with modern thinking. Three departments formed the nucleus of the new university; the department of fine arts (Kala Bhavan), the department of music (Sangit Bhavan), and the department of Indology, founded for the study of Buddhist literature, Vedic and Classical Sanskrit, Pali, Prakrit and later on Tibetan and Chinese. Soon it became associated with scholars and visitors from all over the world and claimed Satyajit Ray, Indira Gandhi and Amartya Sen as some among its famous alumni.

Tagore founded the university, but had no definite plans for its future course. "I do not put faith in any new institutions, but in the individuals all over the world who think clearly, feel nobly and act rightly," he wrote at the very time he started the university. In response to a 
request to define his dream more clearly he replied, "I find it rather difficult to answer your question...In writing my stories I hardly ever have a distinct plot in my mind. I start with some general emotional motive which goes on creating its story form very often forgetting in the process its ...original boundaries. If I had in the commencement a definite outline which I was merely to fill in, it would certainly bore me - for I need the constant stimulation of surprises... The same thing happened with my Shantiniketan Institution. I merely started with this simple idea that education should never be disassociated from life."22

One thing that was certain in Tagore's mind was that Visva-Bharati was not to be a conventional degree peddling institution. But the high ideals of openness, open to new ideas, open to accept European renaissance through modern science became difficult to implement within the framework of a large institution. A steady stream of distinguished visitors came to visit Tagore and Shantiniketan. Most of them went away impressed with idea, but "unconverted with the actuality." One such distinguished visitor was, E.M. Forster, who came in 1945, four years after Tagore's death. He said to his hosts;

I am not here to pass any verdict on India nor do I fortunately carry the white man's burden on my shoulder. All that I carry around my neck is the pleasant light burden of a lovely garland of marigold, which, I feel, is the symbol of your love and friendship.

But to an English friend he was more frank:

We went over for a night to [the] shrine. It was less shriney than I expected, indeed there were some sensible remarks about the Passed Master. Much kindness, and my two companions (Muslims) were moved, as was I. I am afraid that the place does not cut much ice now, except as through the elderly and theosophic. The educational side of it is too casual. ${ }^{23}$

Indeed long before Bose became the Vice Chancellor, Tagore's ideal university had ceased to exit. For the first time, a full-time administrator, Bose went to Visva-Bharati full of new ideas. But what he soon discovered was a rigid way of life, adhering to narrow rituals and insular to change. Visva-Bharati till then did not have a basic infrastructure for scientific research. It offered science courses only up to the Intermediate level. Bose wanted to introduce advanced courses leading up to the graduate and post-graduate level. He wanted to build an Advanced Center of Science. He often spoke to the students about the role of science in every day life. He had such innovative ideas, for example, of building a small experimental plant which would use kitchen garbage as fuel and produce manure as well as methane gas for the classroom experiments. ${ }^{24}$ This emphasis on science and breaking of some of the long established traditions of the university did not go well with the Executive Council. It harbored the false idea that "Gurudev Rabindranath Tagore", the founder of the institution, was antiscience. Science was at the root of materialism and contrary to the humanistic goals set by the founder. Bose failed to implement any of his ideas. Frustrated, he resigned from his position as the Vice Chancellor and returned to Calcutta at the end of 1958. 


\section{Professor Emeritus; National Professor}

Calcutta University had appointed Bose, on his retirement, an Emeritus Professor and had allowed him to keep his former Khaira Professor office for holding seminars and discussions. He returned with the idea of devoting himself to research, particularly in the new developments in nuclear physics and complete some of his earlier work in organic chemistry. He had research laboratory facilities and a grant from the Indian Association for the Cultivation of Science. In 1959 he was appointed a National Professor, the highest honor which the nation could confer upon a scholar. He held it for three successive terms, each lasting five years.

For the rest of his life, Bose continued to live in Calcutta. He was one of the last survivors of the brilliant young men that had entered the University some sixty years ago. In the final phase of his career, Bose followed a distinctively different style in his scientific pursuits. His domain now went beyond basic research and beyond Khaira laboratory. The problems he became interested in were more in the applied areas of wider interest to the society at large. One such project was the extraction of helium from the hot springs of Bakreswar. The existence of helium in the radioactive water of hot springs was first detected by Syamadas Chatterjee at the University of Jadavpur. But it was through the efforts of Bose, who fully realized its strategic importance, that a field study unit was set up to collect the gas at the site and make a systematic analysis at the National Professor's laboratory. He made himself available, as in his academic life, to any group of young enthusiastic scholars undergoing training in diverse branches of science. "Tempered by the years, with his luxuriant crop of white hair, he came to be regarded a sort of father confessor, giving counsel on any problem on which anyone sought his guidance. To him may be applied what Francis Bacon said about himself: I have taken all knowledge to be my province." 25

Bose also became a strong advocate of modern science. Both Saha and Bose rose against a chauvinistic view that the Indian ancients knew it all - it was all there (including Einstein's relativity) in the Vedas and the scriptures. Bose was among the pioneers who realized the importance of science education in one's own mother tongue for its better foundation among young students. After his return to Calcutta from Dacca, he was instrumental in inaugurating the society called Bangiya Bijnan Parishad. ${ }^{26}$ Under its auspices it began publishing a monthly periodical, called Jnan O Bijnan, a Bengali version of Science and Culture, the organ of the Science News Association started a decade earlier by Saha. The journal with provocative articles on science and religion, with popular articles on the latest discoveries in science and a section for children contributed significantly to a deeper and wider appreciation of science in Bengal.

In Calcutta, Bose's initiatives in teaching in Bengali did not go well. His lectures in Bengali in advanced courses were remembered, but met with ridicule and criticism from stalwarts who were not convinced that the Bengali language was a suitable medium for teaching highly technical ideas. For them, he found a good response. During his visit to Japan as the invited guest (1962) for a symposium on Science and Philosophy, he found that physics was taught in Japanese, research papers were being written in Japanese, even at seminars all discussions were conducted in Japanese. He returned from Japan firmly convinced that only the use of 
one's mother tongue can bring out the best in every individual. With the prestige of a National Professorship and plenty of freedom to think, write, and do as he pleased, Bose continued his crusade for the mother tongue along with his scientific research and projects. He also became involved with Indian Statistical Institute, as Vice President (1960-1967) and President from 1967 till the end of his life.

On his eightieth birthday, nationwide celebrations were organized. It was also the fiftieth anniversary of the discovery of Bose Statistics. An International Symposium in his honor took place in Calcutta. It was attended by prominent scientists from many countries and the proceedings of the symposium ${ }^{27}$ record the impact Bose's work has had on so many diverse fields. Bose, responding to the occasion, spoke about his long years of struggle, and expressed his satisfaction at having seen his work appreciated and said "Now I feel I do not need to live any longer." It was a prophetic remark. The activities associated with the celebration, the receptions, seminars and exhibitions took a heavy toll on his health. After an attack of bronchial pneumonia, he died on the 4 February, 1974, only a month after he had completed eighty.

\section{Conclusion}

All his life Bose remained loyal and grateful to Einstein for his acceptance of his short paper and making it known in the scientific world. He had unbounded admiration for Einstein's scientific achievements. He called him the champion of the oppressed Jews and deplored antiSemitism that drove him out from his native land. He wrote to him on 9 December, 1945, ${ }^{28}$

As one who owes so much to you and your guidance in life, I have always been anxious to have news of yourself, especially under the new conditions when you are in a new country. Some of my friends who are more lucky than me, had chances to visit the States recently, and had the good fortune of seeing you in your new house. I am glad to know that you are well, and still take a lot of interest in India and Indians.

It is unfortunate he did not get a chance to see him again after 1925. Other than a few instances in informal discussions he kept his disagreements with Einstein to himself for the most part. 29

Bose had a large family of five daughters and two sons (two other children died as infants). He was considerate and caring without being overly indulgent. They all grew up in a relaxed and loving family atmosphere. The only advice he gave them was to be honest and sincere. Ushabati, simple and unassuming, never made her presence felt. Bose, endearing and loving, did his best to make her life easy in the extended family. Unlike traditional husbands, he was very thoughtful of her in many small ways. "If she slept late, Satyendranath would take care of arranging breakfast for the children, prepare for himself a couple of toasts and tea and then rush off to college." 30 To the end he remained modest, friendly and easily accessible. His door was always open to anybody who cared to come in. He was completely at ease with people who had no idea of his achievements in science. 
Judged against conventional standards, Bose's achievements in scientific research were not as sustained or as numerous as those of his contemporaries like C.V. Raman, M.N. Saha and K.S. Krishnan. Various interpretations could be made of this. Mostly self-taught under difficult circumstances, lacking books and journals, with responsibilities of heavy teaching both theory and experiments, Bose after great initial success fell into the trap of being a perfectionist, publishing only what he considered were worthwhile ideas. He never kept any notes, lecturing by memory. Many of his ideas ended up in students' theses.

Bose was a towering figure in many other ways. With his love for stimulating conversations, his wide ranging interests in all human endeavors and his intellectual fervor, he was a source of inspiration for many outside physics. A voracious reader with mastery in French, German and Sanskrit, he was also a connoisseur of classical music and played the instrument Esraj. More interested in absorbing new ideas than expressing them in print, his ability to tackle problems in entirely new fields was legendary. "...his keen, perspicuous and versatile mind," says B.M. Udgaonkar, "trained in the method of physics and mathematics was allowing itself to range over a variety of fields, including chemistry and biology, soil science and mineralogy, philosophy and archeology, arts, literature and music." 31

He was active politically throughout his life, serving on many committees to further the scientific and industrial development of India after Independence. Politically, the partition of India in 1947 had particularly disillusioned him. A free India - but mutilated! He was a fervent Bengali nationalist, and like Rabindranath Tagore, was a strong advocate and practitioner of writing and teaching in Bengali. To summarize, in the words of Partha Ghose, "Bose was indeed a unique confluence of intellectual brilliance, encyclopedic knowledge, selfless dedication to the motherland and unbounded compassion and love for fellow beings. He was a renaissance figure and a quintessential Bengali." ${ }^{32}$

\section{References and Notes}

1. The Early Phases of My Exploration in Science, S.N. Bose, (The Man and His Work, Part II, p. 246). [This article is included in this volume].

2. Ibid. p. 247.

3. The first two papers they wrote together were: On the Influence of Finite Volume of Molecules on the Equation of State, Phil. Mag., Sr 6. 36, 199, 1918; On the Equation of State, Phil. Mag., Sr 6. 39, 456, 1920. [Both these papers are included in this volume].

4. The Principle of Relativity, The Original Papers by A. Einstein and H. Minkowski, translated into English by M.N. Saha and S.N. Bose with a historical Introduction by P.C. Mahalanobis, University of Calcutta 1920.

5. There are conflicting accounts regarding the sequence of events that led Bose to send the manuscript of his first paper to Einstein. My account is based on those of W.A. Blanpied and John Stachel. See the articles, Satyendra Nath Bose: Co-Founder of Quantum Statistics by W.A. Blanpied and Einstein and Bose by John Stachel included in this volume.

6. The Golden Age of Theoretical Physics, Jagdish Mehra, (World Scientific, 2001) p. 514.

7. In the Company of Madame Curie, S.N. Bose (The Man and His Work, Part II, p. 290). [The article is included in this volume]. 
8. Bose Statistics: A Historical Perspective. Partha Ghose (The Man and His Work, Part I, pp. 35-71). [This article is included in this volume].

9. Private communication (Partha Ghose).

10. Sylvain Levy, the great French orientalist and a friend of Jacqueline's father Lèon Zadoc, knew Bose as a famous physicist. He introduced him to his friend's daughter, a budding young physics student.

11. The Golden Age of Theoretical Physics, Jagdish Mehra, (World Scientific, 2001) p. 526.

See also The Historical Development of Quantum Theory, Jagdish Mehra and Helmut Rechenberg (Springer Verlag), p. 571.

12. Einstein and Bose, by John Stachel in Einstein from ' $B$ ' to ' $Z$ ' (Birkhäuser, 2002), p. 527. [This article is contained in this volume].

13. Satyen Bose in Berlin Purnima Sinha (The Physicist, Bulletin of the Bangladesh Physical Society, Jan-Feb 1995). [This article is contained in this volume].

14. Herman Mark expressed these views more formally in his recommendation letter, "... His large and profound knowledge which stretches over the whole of physics as well as the wider territory of chemistry marks Mr. Bose out prominently. His most valuable quality which makes him of inestimable value to a collaborator is his deep and clear insight in the fundamentals of our science, his wealth of fruitful ideas and his capacity to combine theoretically important questions with experimentally feasible tests in an exceedingly happy manner...".

15. Einstein (1965) S.N. Bose (The Man and his Work, Part II, p. 288).

16. S.N. Bose: The Man. Partha Ghose (Talk presented at a seminar on Albert Einstein, Dhaka, 30 May, 2005; Published in the Proceedings of Bangaladesh Academy of Sciences).

17. In 1928 Arnold Sommerfeld came to India. During his visit to Calcutta, Raman arranged a grand function at the Indian Association for the Cultivation of Science and gave his talk on the newly discovered phenomenon. Bose, who had come from Dacca to meet Sommerfeld, after listening to the talk and seeing the spectrum, had said to Raman, "Professor Raman, you have made a great discovery. It will be called the Raman Effect, and you will get the Nobel Prize."

18. This camera, the then most modern equipment of an X-ray crystallographer, was first fabricated by a mechanic in the laboratory workshop in Dacca University under the guidance of Bose.

19. At the request of Professor Asesh Das, Royal Society released the following information in 2008 concerning the names of the supporters of the nomination and election of Bose to a Fellowship of the Society in 1958 after the mandatory 50 years had passed.

From general knowledge:

Douglas Hartree, Max Born, Maurice Pryce, Cecil Powell, Frederick Frank, and Edward Guggenheim. From personal knowledge:

Paul Dirac, Patrick Blackett, John Cockcroft, Alan Wilson, Rudolf Peierls, Homi Bhabha.

20. I am indebted to Etienne Eisenmann for this information regarding his mother and his family.

21. Rabindranath Tagore: The Myriad-Minded Man. Krishna Duttanand and Andrew Robinson (St. Martin's Press, New York, 1995) p. 205.

22. Ibid. p. 10.

23. Ibid. p. 11.

24. Satyendra Nath Bose. Santimay Chatterjee and Enakshi Chatterjee (National Book Trust. India, 1993) p. 60.

25. S.D. Chatterjee (The Man and His Work, Part II) p. 94.

26. Concerning the details of the resolution to form the society and its objectives, see (The Man and His Work, Part II) p. 96. 
27. The Proceedings of this symposium were published under the title Statistical Physics Symposium Celebrating Fifty Years of BOSE STATISTICS. Edited by N. Mukunda, A.K. Rajagopal and K.P. Sinha, (Indian Institute of Science, Bangalore 1975).

28. Doc. 6-134, Einstein Archives, Hebrew U. of Jerusalem, Israel.

29. See S.N. Bose by Partha Ghose; Ref. 16.

30. The Man and the Work, Part II, p. 104.

31. The Unconventional Scientist, by Santimay Chatterjee and Enakshi Chatterjee, Science Reporter, January 1994, p. 19.

32. Partha Ghose; Ref. 16. 